\title{
Qualitative Analysis of Covid-19 on Working Women
}

\author{
Konica Kansal \\ Research Scholar, Lovely Professional University, Jalandhar \\ DOI: 10.29322/IJSRP.10.06.2020.p10208 \\ http://dx.doi.org/10.29322/IJSRP.10.06.2020.p10208
}

\begin{abstract}
The corona-virus (COVID-19) pandemic is the greatest challenge that we have faced and defining global health crisis of the current time in India. The World Health Organization, which has officially declared the outbreak a pandemic, has called on "all countries to continue efforts that have been effective in limiting the number of cases and slowing the spread of the virus." However, the rest of the country remains under lockdown. Due to which the country is under lockdown the companies has been shutdown, people are staying where they are. All the travelling, tangible business meetings, schools, colleges, hotels have been prohibited to execute their operations. Work from Home is the only practice which can help to continue the business operations and functions. The dynamics of the working environment have exerted huge pressure on working women as they need to handle with two full time jobs - one at home and the other at office. Working women have a difficulty to balancing the family and work. Work life balance is necessary for women to cope with the family and work. Thus this research paper focused on the impact of COVID-19 on the working women and also give suggestions to balancing their life during pandemic situation. The native of the research is qualitative research, data collected from 30 working women through telephonic interview. By using content analysis technique this study revealed some positive and negative impact on working women like negative aspects are Workload, Monotonous routine, Stress and Bleak future aspects and positive aspects are Family time, flexible working hours, vocational learning and Focus on health. Thus this study will help the working women during lockdown.
\end{abstract}

Index Terms- Covid-19, Work Life Balance, Working Women

\section{INTRODUCTION}

$\mathrm{I}^{\mathrm{n}}$ n India and many other countries, is a complete lockdown due to the COVID-19 global health crisis. Families are required to stay indoors, mostly the women who are bearing the stress of the situation. While the women can have it work, ambition, family and a dream home is undoubtedly motivating and positive for women to strive and do better, but, in these testing times, it's causing several women to crack under pressure.

The psychological impact of the corona-virus is worse for women than men because women are at higher risk due to virus as per the research by Richmond Foundation, a mental health organization. This study involved 1,064 individuals and showed that $48 \%$ of them often experienced a sense of apathy and $47 \%$ of the responders were feeling depressed. Woman do two jobs one from inside the house and another is outside the house. It is difficult to maintaining the coordination between family and job for any married women or single mother, it is found that the disputes are created in the family of working women whether she is educated or not and have burnt through their savings during this lockdown. Apart from this, the crisis had forced family time is generating new creative genres and reminded us that our psychological wellbeing gets affected. Despite this we are able to rise to the occasion and help, remain optimistic when we wake up from this long sleep comfort and take care of each other, and this long pause, we will be ready to take on the new challenges with dedication and vigour. Working women spending more time with family, communication between parents and children, and between life partners has improved. Thus Work-life balance assumes be a great significance for women as they are virtually in two full time jobs - one at inside home and the other outside the home . During lockdown women often find it difficult to maintain balance of pressures of work and demands at home. The study of dispute and problems created due the job in family is popularly known as "Work-Life Balance." Marks and MacDermid (1996) reveled that balanced individuals experienced greater role ease, less depression and less role overload their imbalanced counterparts. Thus it is important that women know to balance between work and home activities for a happy life during lockdown to avoid conflicts, stress and misunderstanding. In this research paper researcher study the impact COVID-19 on working women.

\section{REVIEW OF LITERATURE}

Traditionally, the percentage of men as wage earners were high and women as housewives were low . But now in modern India, the percentage of dual-earner couples is gradually increasing and changes in the workforce are go along with changes in values, and creating a new emphasis on the balance between work-life and family life (Hall,1990). Work-life balance assumes great significance for women as they are virtually in two full time jobs - one at home and the other at office. Working mothers often have to challenge stereotypes and perceptions that evolve as a working woman becomes a working mother. Women often find it more difficult to maintain balance the pressures of work and demands at home. Working women have to carefully handle their personal balance and skillfully blend their roles, so as to optimize their potential in all quadrants of life. To understand it in a better way, it is essential to review a previous literature about the women domestic workers which helps to enhance the knowledge about them in a broader perspective. According $\mathbf{V}$. Yawalkar\& M. Sonawane, 2016 work-life balance was a concept including proper prioritizing between "lifestyle" i.e. 
health, leisure, family and spiritual development " and "work" and ambition i.e. career. It indicates the importance of work-life balance for a women was sound and stable family relationship. It was assumed that attitudes at work was carried over into home life (Kando and Summers 1971) or that work attitudes affect a basic orientation towards the self, others and children (Clark,2001).

\section{OBJECTIVE OF THE STUDY}

To study the impact of COVID -19 on the working women job and domestic work balance, researchers intended to study with the following objectiveswomen.

1. To study the impact of COVID -19 on the working

2. To suggest the recommendations for maintaining worklife balance during lockdown

\section{METHODOLOGY}

Method: The present study primarily aims to describe the qualitative description of the impact of COVID-19 on working women. The data are collected in the form of some narrative description for understanding and deriving necessary interpretation regarding impact on women.

Sampling: A purposive sampling is used which is valuable sampling type for special situations. In the current analysis twenty working females (age 30-35) were selected. For the collection of data, telephonic interviewing and close contact of the researcher with the participants were use.

Tools: A content analysis technique was used to examine the information or content and symbols contained in written documents or other communication media such as telephonic conversation or e-mails .So here, to conduct a content analysis, some negative and positive impact were. The investigators identified eight domains - four negative aspect of lockdown

(Workload, Monotonous routine, Stress and Bleak future aspects) and four positive aspects of (Family time, flexible working hours, vocational learning and Focus on health) lockdown among the participants taken into considerations.

Procedure: In the present study the participants were selected by close contacts as everyone is undergoing this lockdown globally. Participants were working women and then they were contacted over telephonic interviews as because social distancing need to be maintained during this pandemic situation. The nature of the study was explained properly to the participants and at the same time it was also mentioned that the information would be kept confidential. Some positive and negative aspects had been identified that the participants might show during this lockdown state. The responses of the selected participants were recorded over the telephone. As the present study emphasized on qualitative research, content analysis method had been used to collect the data and interpreting the texts or content received or recorded from the participants.

\section{RESULTS}

\section{Objective1. To study the impact of COVID -19 on the working women.}

Table 1 \& 2: shows the Negative \& Positive impact of Lockdown on working women

Table 1: Domains of Negative Aspects

\begin{tabular}{|c|c|c|c|c|}
\hline & WORKLOAD & $\begin{array}{l}\text { MONOTONOUS } \\
\text { ROUTINE }\end{array}$ & STRESS & $\begin{array}{l}\text { BLEAK } \\
\text { ASPECTS }\end{array}$ \\
\hline $\begin{array}{l}\text { Married } \\
\text { working } \\
\text { women }\end{array}$ & $\begin{array}{l}\text { Many professional } \\
\text { women, found it } \\
\text { especially stressful and } \\
\text { difficult because to be } \\
\text { working from home as } \\
\text { well as doing household } \\
\text { chores, other activities } \\
\text { without much support } \\
\text { from their partners, thus } \\
\text { it was added load. Men } \\
\text { who used to go out for } \\
\text { work and children used to } \\
\text { go out for school are at } \\
\text { home and creates a } \\
\text { demanding situation for } \\
\text { women. As the house is }\end{array}$ & $\begin{array}{l}\text { Covid } 19 \text { and the resulting } \\
\text { lockdown has led to a } \\
\text { monotonous kind of a life } \\
\text { people are living the same } \\
\text { day over and over. } \\
\text { Especially the working } \\
\text { women who stuck at home } \\
\text { are juggling between the } \\
\text { household and their office } \\
\text { work requirements this is } \\
\text { getting tiresome and } \\
\text { causing irritation and } \\
\text { frustration. Since they are } \\
\text { accustomed to their } \\
\text { dynamic office routine,it is } \\
\text { proving difficult for them to }\end{array}$ & $\begin{array}{l}\text { Women who quit their job } \\
\text { just before the lockdown, } \\
\text { the quarantine has brought } \\
\text { with it an unending streak } \\
\text { of days when they can't } \\
\text { seek work out. Thus with } \\
\text { no work in hand they } \\
\text { feeling very unproductive } \\
\text { all day and it's making } \\
\text { scary fact that they are } \\
\text { living in times of pandemic } \\
\text { is adding to the stress. Pay } \\
\text { cut itself brings with a lot of } \\
\text { stress. Due to Stress and } \\
\text { anxiety women are facing } \\
\text { health issues and change in }\end{array}$ & $\begin{array}{l}\text { The struggle does not end here. } \\
\text { Working women single or } \\
\text { married, face a difficult } \\
\text { financial future. A single } \\
\text { mother burnt their all saving } \\
\text { because of jobless, now they } \\
\text { are worried how to pay school } \\
\text { fees, rent and another day to } \\
\text { day expenses. Some women } \\
\text { who are working hourly basis } \\
\text { job worried about their job }\end{array}$ \\
\hline
\end{tabular}




\begin{tabular}{|c|c|c|}
\hline $\begin{array}{l}\text { small and people are at } \\
\text { home all the time, which } \\
\text { is creating lack of } \\
\text { emotional space as well. }\end{array}$ & $\begin{array}{l}\text { adjust to this new } \\
\text { monotonous routine. }\end{array}$ & sleep patterns. \\
\hline
\end{tabular}

Table 2 : Domains of Positive Aspects

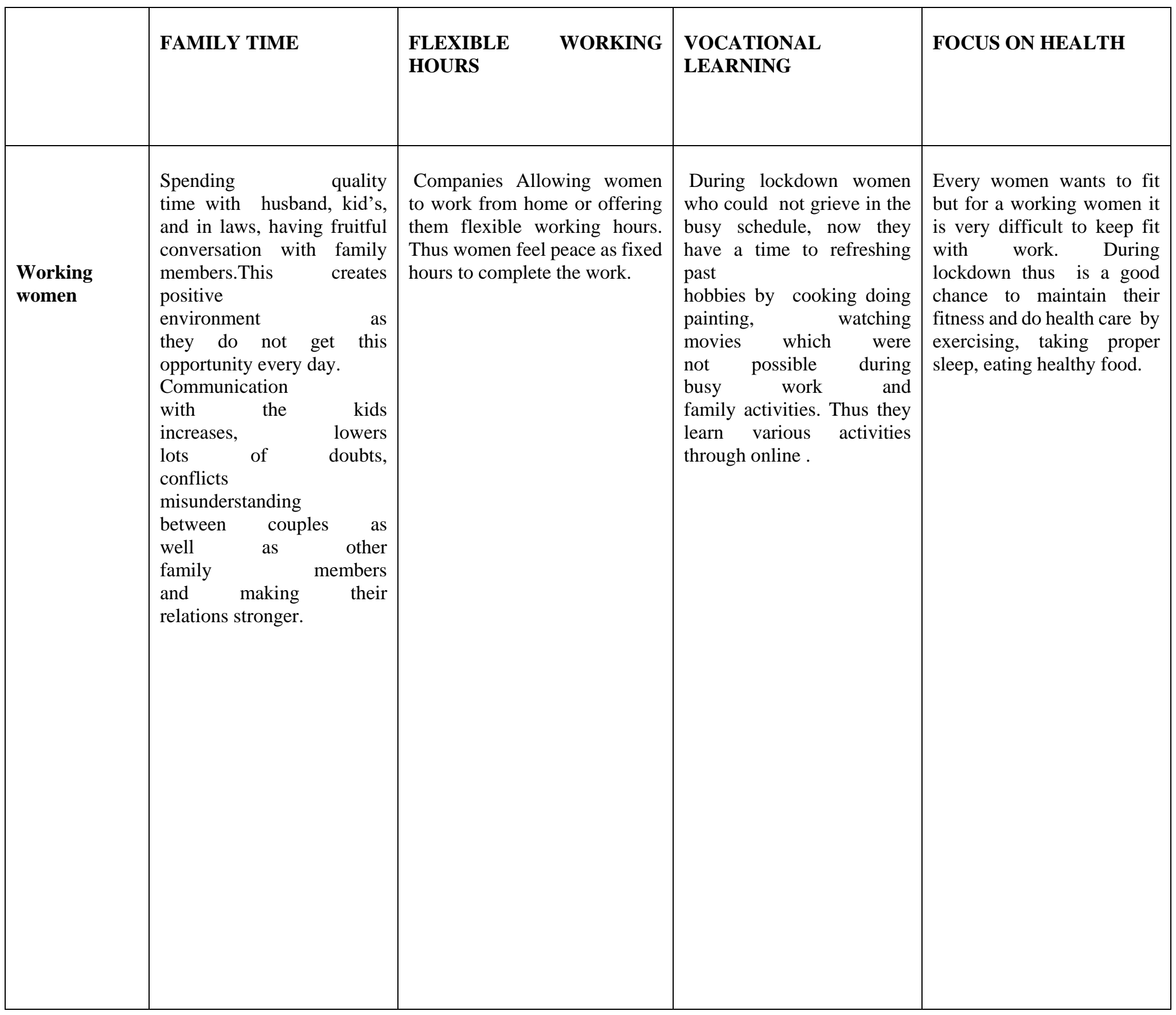




\section{Objective 2: To suggest the recommendations for maintaining work-life balance during lockdown}

1. The ongoing economic crisis has lead to bleak future aspects. Untill normalcy is restored, there is constant need to be in touch with your clients to maintain good rapport. Also, efforts should be made to speak with colleagues and supervisors to assure them of your availability in this ardent need of the hour.

2. Women Schedule their working hours and setting up dedicated times for work so this will help to relax in down time.

3. Prioritize their task correctly so that time to be dedicate an equal amount of attention to your dear ones and work. Identifying at what time during the day you are most productive is your best option.

Taking caring is extremely important, so try to begin your day with some meditation and recreational exercise, try to spend time with kids.

5. Women can seek involvment from their respective partners in reducing their workload which will in-turn enable them to spend more time together.

\section{CONCLUSION}

The analyses of this study are an attempt to understand the impact of COVI19 on working women. In Indian, women are rarely given top priority to career and primarily responsible for their family. This study has revealed that during lockdown working women do work from home they feel burden of excessive office and house work. To fulfill family expectations and not having time for themselves are the prime factors affecting work life balance of working women. As a consequence many women suffer high level of stress and anxiety and also do not enjoy family life. Informal discussions with working women revealed that those who had family or husband support and flexible work schedule enjoyed better work life balance. The above findings have shown the positive and negative consequences of working women life balance. It also provides suggestion to maintain healthy work life balance during lockdown.

\section{LIMITATION OF THE STUDY}

Since this study is an action research, so it is conducted in a pragmatic situation. Due to the COVID-19 pandemic the country is under lockdown. So the only way to collect data was the telephonic in depth interview. The sample size is 30 which may not be applicable to generalize the whole population of the study. The qualitative data analysis requires time and patience. This research has been conducted in short of time. The data collection technique ,i.e. telephonic interview suffered a lot of a communication, availability of the interviewee and technological barriers.

\section{REFERENCES}

[1] Balaji, R. (2014). Work life balance of women employees. Internationa Journal of Innovative.

[2] Clark, S. C. (2001). Work cultures and work/family balance. Journal of Vocational Behavior, 58(3), 348-365.

[3] Hall, D. T. (1990). Promoting work/family balance: An organization-change approach. Organizational Dynamics, 18(3), 5-18.

[4] Kando, T. M., \& Summers, W. C. (1971). The impact of work on leisure: Toward a paradigm and research strategy. Pacific Sociological Review, 14(3), 310-327.

[5] Khillare, P. Y., \& Sonawane, M. A. (2016). The Impact of Work-Life of Women Domestic Workers on their Family-Life.

[6] Marks, S. R., \& MacDermid, S. M. (1996). Multiple roles and the self: A theory of role balance. Journal of Marriage and the Family, 58, 417-432.

[7] Neuman,L.W.(2015).Social Research Methods: Qualitative and Quantitative Approach

[8] Pearson India Education Services Pvt. Ltd.

[9] Sundaresan, S. (2014). Work-life balance-implications for working women. OIDA International Journal of Sustainable Development, 7(7), 93-102.

[10] World Health Organization. (2020).Coronavirus disease (COVID-19) Pandemic, Latest

[11] updates - Live press conference (Geneva). The U.S. Department of Health and Human Services.

\section{AUTHORS}

First Author - Konica Kansal, Research Scholar, Lovely

Professional University, Jalandhar 